\title{
Reduction of safrole content of Cinnamomum porrectum leaves by blanching and the effect on the antioxidant and anti-inflammatory activities of its herbal tea
}

\section{Phornthip Saetan $^{1}$, Worapong Usawakesmanee ${ }^{1 *}$, Sunisa Siripongvutikorn ${ }^{1}$ and Chutha Takahashi Yupanqui ${ }^{2}$}

${ }^{1}$ Department of Food Technology, Faculty of Agro-Industry, Prince of Songkla University, Hat Yai, Songkhla, Thailand; ${ }^{2}$ Interdisciplinary Graduate School of Nutraceutical and Functional Food, Prince of Songkla University, Hat Yai, Songkla, Thailand

*Corresponding Author: Worapong Usawakesmanee, PhD, Department of Food Technology, Faculty of Agro-Industry, Prince of Songkla University, Hat Yai, Songkhla, Thailand

Submission Date: August $3^{\text {rd }}, 2017$, Acceptance Date: December $28^{\text {th }}$, 2017, Publication Date: December $31^{\text {st }}, 2017$

Citation: Saetan P., Usawakesmanee W., Siripongvutikorn S., Yupanqui C.T., Reduction of safrole content of Cinnamomum porrectum leaves by blanching and the effect on the antioxidant and anti-inflammatory activities of its herbal tea. Functional Foods in Health and Disease 2017; 7(11): 936-957. https://doi.org/10.31989/ffhd.v7i12.382

\begin{abstract}
Background: Cinnamomum porrectum $(C$. porrectum) is an aromatic medicinal plant from southern Thailand. While many Cinnamomum species demonstrate medicinal properties such as anti-inflammatory effects, some species are known to contain safrole, a group $2 \mathrm{~B}$ carcinogen. Although the leaves of $C$. porrectum are used to produce herbal tea, there is no scientific data to support its properties as a functional food or any guarantee of its safety.

Objective: To determine the effect of blanching before drying of $C$. porrectum leaves on their safrole content, phenolic profile, total phenolic content (TPC), and total flavonoid content (TFC), antioxidant and anti-inflammatory activities were compared to leaves dried with hot air.
\end{abstract}

Methods: In the first part of the study, the leaves were dried in three conditions: freeze dried $(\mathrm{F})$, hot air dried at $60{ }^{\circ} \mathrm{C}(\mathrm{C})$, and blanched for 60 seconds at $100{ }^{\circ} \mathrm{C}(\mathrm{B})$ before being dried at $60{ }^{\circ} \mathrm{C}$ until the moisture content reached $5-7 \%$ and then were ground and sieved to make powders. The F, C, and B were extracted by methanol and redefined as FM, CM, and BM, for the determination of their chemical constituents by GC-MS using C. porrectum wood oil (CWO) as the safrole standard. In the second part of the study, the $\mathrm{C}$ and $\mathrm{B}$ powders were analyzed for their proximate composition and were also used to make herbal tea infusions (CT and BT respectively) which were analyzed for their phenolic profile, TPC, TFC, antioxidant activities, cytotoxicity, and anti-inflammatory activity in RAW 264.7 cells. 
Results: Significantly decreased safrole contents of $89 \%$ and $82 \%$ were found in the BM sample when compared with CM and FM respectively. The CT and BT had similar phenolic profiles but different contents. The TPC, TFC, ABTS, and FRAP activities, in addition to cell viability and the nitric oxide inhibition of BT were higher than that of CT.

Conclusion: The results demonstrate how blanching $C$. porrectum leaves before drying can decrease the safrole content when compared to freeze dried and hot air-dried leaves, thereby leading to a decrease of cytotoxicity in RAW 264.7 cells. Additionally, BT demonstrated a more intense phenolic profile, TPC, ABTS, and FRAP compared with the un-blanched control sample.

Keywords: $C$. porrectum, freeze drying, hot air drying, blanching before drying, safrole, RAW 264.7 cells.

\section{BACKGROUND}

Oxidative stress is the result of a chemical imbalance between antioxidants and pro-oxidants, oxidants, or reactive oxygen species (ROS). This imbalance leads to damage to important biomolecules and cells, which potentially impact the whole organism [1,2]. Under sustained environmental stress if ROS are produced over a long period, then significant damage may occur to cell structure and function [3], DNA, proteins, and lipids [4, 5, 6], in addition to being closely related to aging and some chronic diseases $[4,7]$.

Inflammation is recognized as a biological process initiated in response to tissue injury [8]. The inflammation response is a complex self-limiting process precisely regulated to prevent extensive damage to the host. When the self-limiting nature of this protective mechanism is inappropriately regulated, it results in chronic inflammation associated with a number of chronic inflammatory diseases, including Alzheimer's disease and cancer $[9,10]$.

Macrophages are important components of the mammalian immune system and play a key role by mounting an immediate defense against foreign agents prior to leukocyte migration and the production of various pro-inflammatory mediators, including the short-lived free radical NO [11]. Lipopolysaccharide (LPS), a component of the cell walls of gram-negative bacteria, is one of the most powerful activators of NO production in LPS-stimulated RAW 264.7 cells which can be used to screen various anti-inflammatory drugs [12].

Plants are a rich source of natural antioxidants including polyphenolic compounds [12]. They have been found to exert their effect as antioxidants and their anti-inflammatory properties by quenching the free radicals, increasing the antioxidant defense, or by inhibiting the release of pro-inflammatory mediators [6]. For centuries, herbal tea remedies have been used to treat infections, ailments, and diseases [13]. Herbal teas consist of one or more herbal substances intended for oral aqueous preparations produced by means of decoction, infusion, or maceration [14]. Herbal infusions are liquid preparations extemporaneously prepared by pouring boiling water on herbal substances and steeping them for 5 to 15 minutes. Many consumers believe that herbal teas are natural and as safe as the herbs they are made from, in addition to promoting health and relieving illness [6].

Cinnamomum porrectum (Roxb) Kosterm, which has the Thai name Thep-tha-ro belongs to the cinnamomum species of the Lauraceae family and is an aromatic medicinal plant widely distributed throughout southern Thailand [15]. This plant is used in traditional systems of medicine or folk medicine and is indicated in several pharmacopoeias [16]. Many previous studies have reported only the functional activities of its essential oils which have antioxidant, anti-inflammatory, antimicrobial, and anti-diarrheal properties $[9,17,18,19,20,21]$. However, 
some species of Cinnamomum are known to contain safrole such as $C$. carolinense, $C$. Mollissimum, and C. porrectum [17, 18, 22]. In 1976, the International Agency for Research on Cancer classified safrole as a Group 2B carcinogen (possible human carcinogen) [22, 23]. Furthermore, the leaves of Cinnamomum species have been found to not only contain safrole but also methyleugenol (4-allyl- 1.2-dimethoxybenzene) (Figure 1 (a, b)) which has been demonstrated to be carcinogenic and genotoxic [21, 24]. The safe intake level of safrole from food and spices has been set at $1 \mathrm{mg} /$ person/day and that of methyleugenol at $13 \mathrm{mg} / \mathrm{person} /$ day [24]. Overall, while both compounds are highly soluble in alcohol, the solubility in water of safrole is lower at $121 \mathrm{mg} / \mathrm{l}$ than that of methyleugenol which is higher at $500 \mathrm{mg} / \mathrm{l}$ [25].

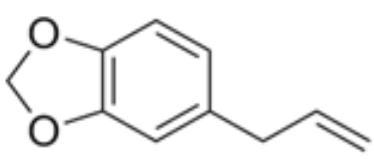

(a)

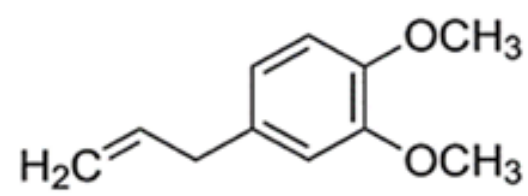

(b)

Figure 1. Chemical structures of safrole (a), methyleugenol (b)

Source: Chen et al. [26] and Tan and Nishida, [27].

In fact, based on a market survey and personal contact, $C$. porrectum leaves are used to make a kind of herbal tea available in some area of Southern Thailand. However, there is no scientific data to guarantee its safety. Furthermore, the phenolic profile, anti-inflammatory activity, and cytotoxicity in cell line systems of $C$. porrectum leaves and the herbal tea made from them have not been studied. However, a previous study discovered that a blanching process can reduce the safrole level in the leaves to levels lower than in hot-air-dried or fresh leaves [26].

In the study reported here, all the samples were extracted with methanol in order to confirm their safrole residue and methyleugenol content. The samples were then analyzed for their chemical constituents using the GC-MS technique. The total phenolic content (TPC) and total flavonoid content (TFC) were established and the antioxidant activity assessed, including DPPH, ABTS, and FRAP assays. A metal chelating assay was also conducted and a phenolic profile constructed. The anti-inflammatory action and cytotoxicity in RAW 264.7 cells were also analyzed in herbal teas prepared from both blanched and un-blanched leaves.

\section{MATERIAL AND METHOD}

Plant materials

Cinnamomum porrectum wood oil (CWO) was kindly provided by the Forestry Technology Research Centre, Songkhla. The developing leaves or leaves at an intermediate stage with a light green to green color and flexible stalks (collected between May and August 2015) were selected from the center. In order to preserve their original quality, the leaves were stored in a refrigerator at $4{ }^{\circ} \mathrm{C}$ and used within 2 days of collection.

\section{Sample preparation}

The leaves were divided into two sets, one for the analysis of their chemical constituents using the GC-MS technique and the other for the determination of their qualities and functional properties. The first set of leaves were divided into three treatments which were respectively freeze-dried (F), hot air dried at $60{ }^{\circ} \mathrm{C}(\mathrm{C})$, and blanched with boiling water at $100{ }^{\circ} \mathrm{C}$ for 60 
seconds before drying at $60{ }^{\circ} \mathrm{C}$ (B) until the moisture content of all the treatments was between $5 \%$ and $7 \%$. All the dried leaves were then ground and sieved though a 60-mesh sieve. The powders were extracted with methanol at a ratio of $1: 10(\mathrm{w} / \mathrm{v})$ using a sonicator at $50{ }^{\circ} \mathrm{C}$ for 2 hours, then filtered through a $0.22 \mu \mathrm{m}$ filter membrane and stored at $-20{ }^{\circ} \mathrm{C}$ until use. The samples were then redefined as FM, CM, and BM respectively.

From the second set, $\mathrm{C}$ and $\mathrm{B}$ samples were prepared as above and then infused by steeping $1.0 \mathrm{~g}$ of the powder in $100 \mathrm{ml} \mathrm{DI}$ water at $95{ }^{\circ} \mathrm{C}$ for 10 minutes using a water bath to control the temperature. The samples were then filtered and cooled to room temperature $\left(28-30{ }^{\circ} \mathrm{C}\right)$ within 5 minutes and then subjected to freeze drying to produce the samples redefined as $\mathrm{CT}$ and $\mathrm{BT}$.

\section{METHODS}

\section{Safrole content analysis by GC-MS technique}

The CWO was diluted with methanol at an initial concentration of 1:10 (w/v) and the methanolic extracts CM, FM, and BM were analyzed for their chemical compositions by GC-MS following the protocol of Tung et al. [28] with slight modification, using a gas chromatograph-mass spectrometer, 7890 B GC-5977 A MSD (Agilent, USA), equipped with a $30 \mathrm{~m} \times 0.25 \mathrm{~mm}$ VFWAXms. The oven temperature was held for 10 minutes at $40{ }^{\circ} \mathrm{C}$, then raised to $240{ }^{\circ} \mathrm{C}$ at $5^{\circ} \mathrm{C} / \mathrm{min}$ and held for 5 minutes. The injector temperature was $240{ }^{\circ} \mathrm{C}$; and the flow rate of the carrier gas helium was $1.0 \mathrm{ml} / \mathrm{min}$; the extracts were injected manually in the split mode. The relative concentrations of each compound in the CWO and samples were quantified based on the peak area calculated by the analysis program and expressed as a percentage of the total compared with all the constituents and the calculated content compared with the CWO calculated from the component area of the GC-MS data.

\section{Proximate composition and physicochemical analyses}

The Proximate composition of the $\mathrm{C}$ and $\mathrm{B}$ powders including their moisture, protein, fat, fiber, ash, and carbohydrate contents were analyzed following the AOAC [30]. The physicochemical properties of the $\mathrm{C}$ and $\mathrm{B}$ infusions were analyzed including their color quality, (determined as Hunter value; $\mathrm{L}^{*}$ (brightness, $100=$ white, $0=$ black), $\mathrm{a}^{*}\left(+:\right.$ red, -: green), $\mathrm{b}^{*}(+:$ yellow, $-:$ blue $)$ and $-\mathrm{a} / \mathrm{b}$ expressed as green, yellow color), total soluble solids, total acidity (expressed as $\mathrm{mg}$ of citric acid/g sample, $\mathrm{pH}$ (AOAC, [30]), total and reducing sugar (expressed as mg glucose/g sample [31]), and total protein content (expressed as mg BSA per g sample [32]).

\section{HPLC analysis}

HPLC analysis was carried out using a high-performance liquid chromatograph (HPLC, (Waters 717 Autosampler-Pump 600-PDA996) fitted with a reverse-phase Purosher ® STAR RP-18 endcapped $(5 \mu \mathrm{m})$ LiChroCART $^{\circledR} 250$ x $4.6 \mathrm{~mm}$ HPLC cartridge. Briefly, $1.0 \mathrm{mg}$ of freeze dried $\mathrm{CT}$ and BT were hydrolyzed with $6 \mathrm{~N} \mathrm{HCl}$ at a ratio of $1: 5(\mathrm{w} / \mathrm{v})$ at $70{ }^{\circ} \mathrm{C}$ for 3 hours. The hydrolyzed samples were filtered through a nylon syringe filter with a $0.22 \mu \mathrm{m}$ pore size before being injected into the HPLC. The gradient mobile phase consisted of $1.0 \%$ trifluoroacitic acid (TFA) in water $(\mathrm{v} / \mathrm{v}), \mathrm{pH} 1.8$ (eluent $\mathrm{A}$ ), and acetonitrile $(\mathrm{ACN})$ (eluent $\mathrm{B}$ ). The gradient condition was set up as followed: $0-5$ minutes, $5 \% \mathrm{~B}$; 5-15 minutes, $10 \% \mathrm{~B} ; 20$ minutes, $15 \% \mathrm{~B}$; $30-35,25 \% \mathrm{~B} ; 40$ minutes $50 \% \mathrm{~B} ; 50 \mathrm{~min} 80 \% \mathrm{~B}$; 51-60 minutes, $100 \%$ A. Elution was performed at a solvent flow rate of $1.0 \mathrm{ml} / \mathrm{min}$ and an injection volume of $10 \mu 1$. Detection was accomplished with a photo diode array detector (PDA) and chromatograms were recorded at 280 $\mathrm{nm}$. The amounts of phenolic acid and individual flavonoid compounds in the extracts were determined using standard curves of phenolic acid and 16 flavonoids $(0.5-20 \mathrm{mg} / \mathrm{l})$ consisting of 
gallic acid, protocatechuic acid, catechin, chlorogenic acid, vanillic acid, caffeic acid, syringic acid, rutin, $p$-coumaric acid, ferulic acid, quercetin, rosmarinic acid, quercitrin, cinnamic acid, apigenin, and kaempferol, in addition to $1-40 \mathrm{mg} / \mathrm{l}$ for tannic acid and 5-200 mg/l for pyrogallol (x-axis) and the peak height of the standard (y-axis).

\section{Total extractable phenolic and total extractable flavonoid content analysis}

The total phenolic content of the freeze-dried CT and BT were determined using FolinCiocalteau reagent. A sample of $50 \mu \mathrm{l}$ was introduced into 96-well plates followed by the addition of $150 \mu \mathrm{l}$ of Folin-Ciocalteu reagent (10 times dilution) and $120 \mu \mathrm{l}$ of sodium carbonate $(7.5 \% \mathrm{w} / \mathrm{v})$. The plates were allowed to stand for 30 minutes in the dark before the determination of their absorbance at $765 \mathrm{~nm}$. Gallic acid, catechin, caffeic acid, $p$-coumaric acid, rutin, and Trolox were used as reference standards and the results were expressed as mg reference standard equivalent per g sample.

The total extractable flavonoid content of the infusions was determined using the aluminum chloride colorimetric method. Briefly, $25 \mu \mathrm{l}$ of the extracts were added into a 96-well plate containing $100 \mu \mathrm{l}$ of water. At zero time, $10 \mu \mathrm{l}$ of $5 \% \mathrm{NaNO}_{2}$ was added, and 5 minutes after 15 $\mu \mathrm{l}$ of $10 \% \mathrm{AlCl}$ was added. Afterwards, $50 \mu \mathrm{l}$ of $1 \mathrm{M} \mathrm{NaOH}$ was added into the mixture and the volume was made up to $250 \mu \mathrm{l}$ with water. The absorbance was measured at $510 \mathrm{~nm}$. Gallic acid, catechin, and rutin were used as reference standards and the results were expressed as $\mathrm{mg}$ reference standard equivalent per $g$ sample.

\section{DPPH radical scavenging capacity assay}

A DPPH free radical scavenging capacity assay was conducted following the method of Udayaprakash et al. [33]. Briefly, various concentrations of test samples (100 $\mu 1)$ were mixed with $0.15 \mathrm{mM}$ DPPH in methanol. After 30 minutes of incubation at room temperature in the dark, the absorbance was measured against a blank (methanol) at $517 \mathrm{~nm}$ using a spectrophotometer. The DPPH free radical capacity was expressed against a reference standard consisting of pytogallol, gallic acid, catechin, caffeic acid, $p$-coumaric acid, rutin, and trolox equivalents per $g$ sample. Inhibition of the DPPH radical was calculated as a percentage (\%) using the formula:

$$
\% \text { inhibition }=100-\left\{\left[\left(\text { Abs sample }_{\text {-Abs blank }}\right) \times 100\right] / \text { Abs control }\right. \text {. }
$$

$\mathrm{IC}_{50}$ values (concentration of sample required to scavenge $50 \%$ of the free radicals) were calculated from a regression equation, prepared from the concentration of the samples and the percentage inhibition of free radical formation (percentage inhibition of DPPH) was calculated.

\section{ABTS radical scavenging capacity assay}

The ABTS radical-scavenging activity was evaluated following the method of Arnao et al. [34]. $7.4 \mathrm{mM}$ ABTS solution and $2.6 \mathrm{mM}$ potassium persulphate solution were prepared as stock solutions. The working solution was prepared by mixing the two stock solutions in equal quantities. The mixture was allowed to react for 12 hours at ambient temperature in the dark. The mixed solution was diluted by mixing $1 \mathrm{ml}$ of ABTS solution with $50 \mathrm{ml}$ of water in order to obtain an absorbance of $1.1 \pm 0.02$ units at $734 \mathrm{~nm}$. Briefly, a sample of $15 \mu 1$ was mixed with $285 \mu \mathrm{l}$ of ABTS solution and the mixture was left at ambient temperature for 2 hours in the dark. The absorbance was measured at $734 \mathrm{~nm}$ using a micro plate spectrophotometer. A blank sample was prepared in the same manner using water instead of ABTS solution. The ABTS radical 
capacity was expressed against a reference standard consisting of pytogallol, gallic acid, catechin, caffeic acid, $p$-coumaric acid, rutin, and trolox equivalents per $g$ sample.

\section{FRAP assay}

The FRAP was assayed according to the method of Benzie and Strain, [35]. $300 \mathrm{mM}$ acetate buffer (pH 3.6), $10 \mathrm{mM}$ TPTZ (2, 4, 6- tripyridyl-s-triazine) solution dissolved in $40 \mathrm{mM} \mathrm{HCl}$, and $20 \mathrm{mM} \mathrm{FeCl} 3.6 \mathrm{H}_{2} \mathrm{O}$ solution were used as stock solutions. A working solution was prepared by mixing $25 \mathrm{ml}$ of acetate buffer, $2.5 \mathrm{ml}$ of the TPTZ solution and $2.5 \mathrm{ml}$ of the $\mathrm{FeCl}_{3} \cdot 6 \mathrm{H}_{2} \mathrm{O}$ solution. The mixed solution was incubated at $37{ }^{\circ} \mathrm{C}$ for 30 minutes in an incubator and is referred to as the FRAP solution. Afterwards, a sample of $15 \mu 1$, was mixed with $285 \mu$ l of FRAP solution and kept at ambient temperature for 30 minutes in the dark. The ferrous tripyridyltriazine complex (blue colored product) was measured by reading the absorbance at 593 $\mathrm{nm}$. A blank sample was prepared by omitting the $\mathrm{FeCl}_{3}$ from the FRAP solution and distilled water was used instead. Standard curves were made using pytogallol, gallic acid, catechin, caffeic acid, $p$-coumaric acid rutin, and Trolox. The results were expressed as mg of each standard equivalent per g sample.

\section{Ferrous chelating activity (FIC)}

The chelating activity towards $\mathrm{Fe}^{2+}$ was measured using the method of Boyer and McCleary [36]. Briefly, $1.0 \mathrm{ml}$ of each sample substance was mixed with $0.1 \mathrm{ml}$ of $0.2 \mathrm{mM} \mathrm{FeCl}_{2}$. The reaction mixture was allowed to stand for 10 minutes at ambient temperature and then $0.2 \mathrm{ml}$ of $5 \mathrm{mM}$ ferrozine was added. The mixture was allowed to stand for more than 10 minutes at ambient temperature. The absorbance was then read at $562 \mathrm{~nm}$. A blank sample was prepared in the same manner using distilled water instead of the sample and blank samples of each of the substances under examination with the $\mathrm{FeCl}_{2}$ solution excluded and distilled water that was used instead were also prepared. The standard curve was constructed using the ethylenediaminetetraacetic acid (EDTA) ranking from 10-50 $\mu \mathrm{g} / \mathrm{ml}$. The activity was expressed as mg EDTA equivalent per g sample.

\section{Determination of anti-inflammatory activity and cytotoxicity in $R A W 264.7$ cells}

Study of NO inhibitory effect on nitric oxide production in RAW 264.7 cells [37, 38]. In briefly, RAW 264.7 cells were washed with phosphate buffer saline (PBS) free of magnesium and calcium ( $\mathrm{pH} 7.2$ ). The PBS was decanted and cells were harvested with $0.25 \%$ trypsin-EDTA and resuspended with $10 \mathrm{ml}$ of fresh RPMI-1640 medium (pH 7.0) to make a single cell suspension. The viable RAW 264.7 cells were counted at the density of $1 \times 10^{6} \mathrm{cell} / \mathrm{ml}$. One hundred microliters per well of this cell suspension were seeded in each well of a 96-well microplate with $1 \times 10^{5}$ cells/well and allowed to adhere for 2 hours at $37{ }^{\circ} \mathrm{C}$ in $5 \% \mathrm{CO}_{2}$. The medium was then replaced with a fresh medium containing $0.5 \mu \mathrm{g} / \mathrm{ml}$ of Lipopolysaccharide (LPS) together with the test samples at various concentration and then incubated for 24 hours. Each extract and some phenolic and flavonoid compounds were initially filtered through a 0.45 $\mu \mathrm{m}$ sterile filter. All the samples were then diluted in a medium to produce the required concentrations. A hundred microliters sample was added into each well of the microplate to obtain a final concentration of $0.001-20.0 \mathrm{mg}$ powder $\mathrm{DW} / \mathrm{ml}$. The $\mathrm{NO}$ production was determined by measuring the accumulation of nitrite in the cultured supernatant using Griess reagent. The cytotoxicity was also determined using 3-(4, 5- dimethyl-2- thaizoly)-2, 5diphenyl-2H-tetrazolium bromide (MTT) solution of which10 $\mu 1,5 \mathrm{mg} / \mathrm{ml}$ in PBS was added to the wells. After 2 hours of incubation, the medium was removed, and dimethyl sulfoxide 
(DMSO) was then added to dissolve the formazan produced in the cells. The optical density of the formazan solution was measured with a microplate reader at $570 \mathrm{~nm}$. The test compounds were considered to be cytotoxic when the sample-treated group was less than $80 \%$ of that in the control group [39]. L-nitroarginine (LNA) a NO synthase inhibitor, at a concentration of 1-100 $\mu \mathrm{g} / \mathrm{ml}$ was used as a positive control. The inhibition (\%) was calculated using the following equation and the $\mathrm{IC}_{50}$ values were determined graphically $(\mathrm{n}=3)$.

Inhibition $(\%)=[(\mathrm{A}-\mathrm{B}) /(\mathrm{A}-\mathrm{C})] \times 100$

A: LPS (+), Sample (-); B: LPS (+), Sample (+); (C): LPS (-), Sample (-)

Cell viability $(\%)=($ OD sample $/$ OD control $) \times 100$

\section{Statistical analysis}

All experiments were run in triplicate and reported as mean \pm standard deviation. The data of TPC, TFC, and antioxidant activities (compare each standard against other standards) were subjected to analysis of variance (ANOVA) and mean comparisons were carried out by using Duncan's multiple range test at a significant level $\mathrm{p}<0.05$. T-test was used for analysis betweengroup comparisons (control (CT) and blanched treatment (BT).

\section{RESULTS AND DISCUSSION}

\section{Chemical constituents analyzed by the GC-MS technique}

The chemical constituents of CWO quantified by GC-MS chromatogram are represented in Figure 2. The results clearly show that safrole was the main constituent which was confirmed using the CAS\# database with a GC-MS data matching factor of $97.90 \%$. Aside from safrole which made up $92.94 \%$, elemicin (3.58\%) and methyleugenol (1.51\%) were also discovered. This data was in agreement with the findings of Pattanaseree and Anatachoke [40], who reported that the volatile oils from the wood of $C$. porrectum from the Southern Literature Botanical Garden in Songkhla province obtained by water distillation were safrole, elemicin, and methyleugenol the main chemical constituents.

The GC-MS chromatogram (Figure 2) of CM, FM, and BM were identical with regards to the main chemical components such as safrole and methyleugenol. However, the methanol extracted samples showed a higher intensity of methyleugenol than safrole compared to CWO, which may be because safrole can be lost during the drying process by being vaporized to the air, while methyleugenol is stable to air, heat, and light [41].

Based on the result from the GC-MS, all the samples had similar chemical constituents including caryophyllene, safrole, and methyleugenol. The results also indicated that CM contained the highest methyleugenol and safrole contents (4.66\% and 2.36\%) followed by FM (3.92\% and $2.06 \%)$ and BM (1.50\% and $0.26 \%)$. The lowest concentrations of both compounds in $\mathrm{BM}$ showed that the blanching process can decrease the methyleugenol and safrole contents compared to $\mathrm{CM}$ and FM, which may due to hydrolysis, leaching, and thermal degradation effects [42, 43].

The blanching process significantly decreased both safrole and methyleugenol content by $89 \%$ and $87 \%$ and by $68 \%$ and $62 \%$ when compared to the hot air dried and freeze-dried samples respectively. The data from this research can be developed to use in the process of marking herbal tea of $C$. porrectum leaves in order to decrease cytotoxicity of safrole.

This result supports the research of Diaz-Maroto et al. [44], who reported that parsley dried through an air-drying process contained more volatile compounds including monoterpene than 
the product from a freeze-drying process. However, some compounds including acetol were more sensitive to air drying compared to freeze-drying. Moreover, Diaz-Maroto and Cabezudo [45] also reported that freeze drying resulted in substantial losses of oxygenated monoterpenes in spearmint, which explains why better food quality is dependent on a proper drying method.

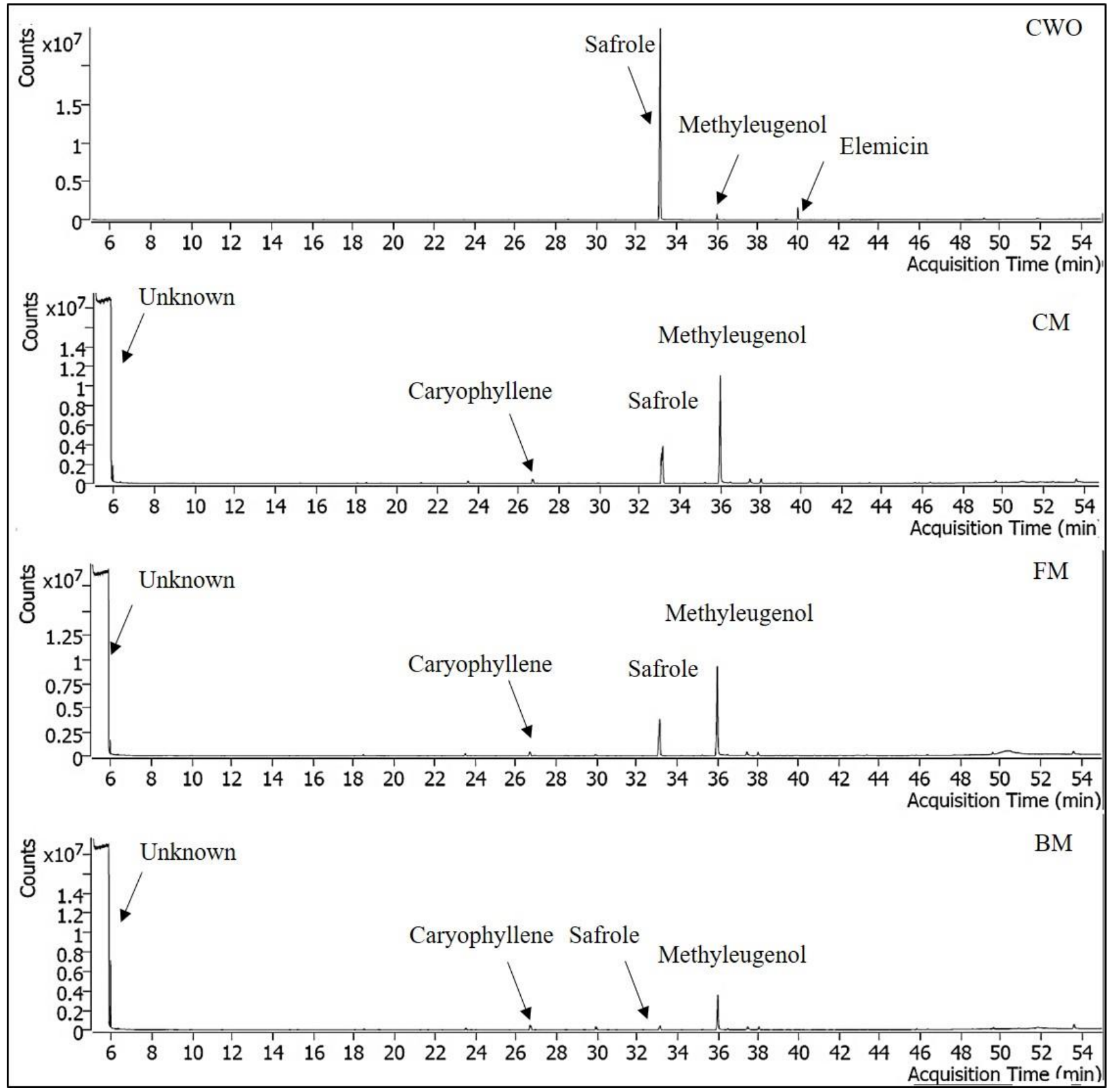

Figure 2. GC-MS chromatogram of CWO, CM, FM and BM.

\section{Proximate composition of herbal tea powders and physiochemical properties of herbal tea infusions}

The proximate composition of the herbal tea powders and the physiochemical properties of herbal tea infusions of CT and BT are shown in Table 1. The moisture content of the powders ranged between $3.64 \%$ and $2.48 \%$. BT had a moisture content lower than that of $\mathrm{CT}$, which may be due to the blanching process causing the powder to lose its structure, leading to easier vaporization during the drying step [46, 47] Additionally, the ash content of BT significantly decreased $(p<0.05)$ which may be due to the leaching effect of the blanching water. This result supported the results of Dugo et al. [48] who reported a loss of minerals during the boiling of 
vegetables and tubers including carrots, bamboo shoots, broccoli, potatoes, and cocoyam due to this leaching effect [49]. However, there was no statistically significant difference in the protein content which was in agreement with Song et al. [50] who reported that the total amino acid and protein content in blanched vegetable soybeans (Glycine max (L.) Merrill) did not change when blanched at $80{ }^{\circ} \mathrm{C}$ for 30 minutes, $90^{\circ} \mathrm{C}$ for 20 minutes, or $100^{\circ} \mathrm{C}$ for 10 minutes. However, Cheftel et al. [51] reported that the solubility of proteins decreased significantly when blanched at $90{ }^{\circ} \mathrm{C}$ and $100{ }^{\circ} \mathrm{C}$ compared to native proteins because of the heating effect. BT was significantly higher in fat and crude fiber content $(\mathrm{p}<0.05)$ than $\mathrm{CT}$ possibly because the blanching process liberated significant fat and crude fiber content. Generally, the structure of plant tissues is opened and loosened through $\beta$-sheet destruction during the blanching process [52], and having a higher porosity leads to increased permeability of the cell walls and improved solvent diffusivity, resulting in an increase in yield extractability [53, 54].

Ando et al. [55] reported that the pectins in the middle lamella were leached away and that afterwards the adhesion of the cell walls was weakened, and the tissue was markedly softened [54] due to this phenomenon. In fact, the increase in the total sugar in BT shown in Table 1 indicates that carbohydrates such as pectin were hydrolyzed. Moreover, during hot water blanching, some part of the hemicellulose may be hydrolyzed and generate acids leading to a decrease in $\mathrm{pH}$. These acids are also assumed to catalyze the hydrolysis of the remaining hemicellulose [56]. The result of the total protein content of BT being lower than that of CT might be due to the protein being stabilized via conjugation with phenolic compounds [57]. The BT infusion had a greener color than $\mathrm{CT}$, which pointed to the blanching process inactivating the chlorophyllase enzyme leading to a higher chlorophyll content in the powder, which plays a key role in the greenness of the tea infusion [47].

Table 1. Proximate analysis and physiochemical properties of $C$. porrectum herbal tea powder and infusion

\begin{tabular}{|c|c|c|c|}
\hline \multicolumn{2}{|c|}{ Parameters } & $\mathbf{C T}$ & BT \\
\hline \multicolumn{2}{|c|}{ \% Moisture content (Fresh leaves) } & $60.87 \pm 0.54^{\mathrm{A}}$ & $60.87 \pm 0.54^{\mathrm{A}}$ \\
\hline \multicolumn{4}{|c|}{ Herbal tea powder } \\
\hline \multicolumn{2}{|c|}{ \% Moisture content (dried leaves) } & $3.64 \pm 0.23^{\mathrm{B}}$ & $2.48 \pm 0.13^{\mathrm{A}}$ \\
\hline \multicolumn{2}{|c|}{$\%$ Ash } & $4.63 \pm 0.05^{\mathrm{A}}$ & $4.37 \pm 0.05^{\mathrm{B}}$ \\
\hline \multicolumn{2}{|c|}{$\%$ Protein } & $8.83 \pm 0.08^{\mathrm{A}}$ & $8.86 \pm 0.09^{\mathrm{A}}$ \\
\hline \multicolumn{2}{|c|}{$\%$ Fat } & $2.41 \pm 0.07^{\mathrm{B}}$ & $3.25 \pm 0.03^{\mathrm{A}}$ \\
\hline \multicolumn{2}{|c|}{$\%$ Carbohydrate } & $80.49 \pm 0.20^{\mathrm{B}}$ & $81.03 \pm 0.22^{\mathrm{A}}$ \\
\hline \multicolumn{2}{|c|}{$\%$ Fiber } & $5.87 \pm 0.56^{\mathrm{B}}$ & $6.55 \pm 0.15^{\mathrm{A}}$ \\
\hline \multicolumn{4}{|c|}{ Herbal tea infusion } \\
\hline \multirow[t]{4}{*}{ color } & $\mathrm{L}^{*}$ & $32.00 \pm 0.06^{\mathrm{B}}$ & $35.24 \pm 0.04^{\mathrm{A}}$ \\
\hline & $a^{*}$ & $1.39 \pm 0.07^{\mathrm{A}}$ & $-0.90 \pm 0.05^{\mathrm{B}}$ \\
\hline & $b^{*}$ & $23.35 \pm 0.08^{\mathrm{A}}$ & $15.52 \pm 0.15^{\mathrm{B}}$ \\
\hline & $-\mathrm{a} / \mathrm{b}$ & $-0.06 \pm 0.00^{\mathrm{B}}$ & $0.06 \pm 0.00^{\mathrm{A}}$ \\
\hline \multicolumn{2}{|c|}{$\% \mathrm{TSS}$} & $0.24 \pm 0.00^{\mathrm{B}}$ & $0.28 \pm 0.02^{\mathrm{A}}$ \\
\hline \multicolumn{2}{|c|}{$\mathrm{pH}$} & $5.62 \pm 0.01^{\mathrm{A}}$ & $5.32 \pm 0.01^{\mathrm{B}}$ \\
\hline \multicolumn{2}{|c|}{ Total acidity (mg citric acid/g) } & $0.70 \pm 0.00^{\mathrm{B}}$ & $0.77 \pm 0.00^{\mathrm{A}}$ \\
\hline \multicolumn{2}{|c|}{ Total sugar (mg glucose / g) } & $181.48 \pm 1.71^{\mathrm{B}}$ & $231.64 \pm 1.69^{\mathrm{A}}$ \\
\hline \multicolumn{2}{|c|}{ Reducing sugar (mg glucose / g) } & $63.11 \pm 0.17^{\mathrm{A}}$ & $60.81 \pm 0.42^{\mathrm{B}}$ \\
\hline \multicolumn{2}{|c|}{ Total protein (mg BSA / g) } & $315.23 \pm 1.83^{\mathrm{A}}$ & $265.62 \pm 2.17^{\mathrm{B}}$ \\
\hline
\end{tabular}

${ }^{\mathrm{A}-\mathrm{B}}$ Means within a row with different letters are significantly different $(\mathrm{p}<0.05)$. 


\section{Phenolic and flavonoid profiles}

From the HPLC-PDA result, significantly different contents were found in differently processed samples, as shown in Table 2. The predominant phenolic acids of both samples were pyrogallol, protocatechuic acid, and p-coumaric acid. The results demonstrated that the BT extract had a higher intensity of the predominant phenolic acids than the CT extract, which may be due to the higher extractability discussed earlier. Generally, phenolic compounds exist in three forms, free, conjugated, and bound. Free and conjugated phenolics are both soluble while bound phenolics are insoluble. The major difference between free and conjugated phenolics is that conjugated phenolics are usually esterified to sugars or other compounds with low molecular masses such as peptides and oligosaccharides $[58,59,60]$, while bound phenolics are covalently bound with cell wall structural components, such as cellulose and proteins [61]. The highest contents and intensity of phenolic and flavonoid constituents were found in BT compared to CT, which may be due to the effect of the hot water blanching, which can break down the hydrogen bonds and increase solubility [56]. The lower viscosity and surface tension of water at high temperatures also increases the mass transfer rates of compounds from the matrix [62], which is important for small phenolics such as pyrogallol and gallic acid. Therefore, BT contained a lower content of low molecular weight phenolics than CT. On the other hand, it is possible that during steeping in hot water, high molecular weight material including hemicellulose was hydrolyzed and more conjugated and bound phenolics liberated [56] including catechin, caffeic acid, $p$-coumaric acid, and rutin.

Table 2. Phenolic acid and flavonoid composition of CT and BT

\begin{tabular}{|c|c|c|c|}
\hline \multicolumn{4}{|c|}{ Phenolic acids and flavonoid compounds ( $\mu \mathrm{g} / \mathrm{g}$ of hydrolyzed extract) } \\
\hline & CT & BT & $\%$ increase $^{\mathrm{C}}$ \\
\hline Pyrogallol & $1143.25 \pm 0.35^{\mathrm{A}}$ & $882.43 \pm 32.00^{\mathrm{B}}$ & -22.81 \\
\hline Gallic acid & $395.10 \pm 12.45^{\mathrm{A}}$ & $240.35 \pm 11.67^{\mathrm{B}}$ & -39.17 \\
\hline Protocatechuic acid & $593.25 \pm 3.04^{\mathrm{B}}$ & $640.40 \pm 21.64^{\mathrm{A}}$ & 7.95 \\
\hline Catechin & $337.85 \pm 43.35^{\mathrm{B}}$ & $400.80 \pm 3.82^{\mathrm{A}}$ & 18.63 \\
\hline Chlorogenic acid & $11.50 \pm 2.26^{\mathrm{B}}$ & $18.50 \pm 3.96^{\mathrm{A}}$ & 60.87 \\
\hline Vanillic acid & $109.05 \pm 3.46^{\mathrm{A}}$ & $101.60 \pm 8.77^{\mathrm{A}}$ & -6.83 \\
\hline Caffeic acid & $128.05 \pm 8.27^{\mathrm{B}}$ & $395.65 \pm 18.46^{\mathrm{A}}$ & 208.98 \\
\hline Syringic acid & $33.80 \pm 7.35^{\mathrm{A}}$ & $36.15 \pm 8.27^{\mathrm{A}}$ & 6.95 \\
\hline$p$-coumaric acid & $563.00 \pm 14.00^{\mathrm{B}}$ & $731.11 \pm 5.94^{\mathrm{A}}$ & 29.55 \\
\hline Rutin & $1878.00 \pm 12.70^{\mathrm{B}}$ & $2676.80 \pm 42.97^{\mathrm{A}}$ & 41.17 \\
\hline Ferulic acid & $42.35 \pm 3.75^{\mathrm{A}}$ & $24.85 \pm 1.48^{\mathrm{B}}$ & -41.32 \\
\hline Quercitrin & $10.84 \pm 3.31^{\mathrm{B}}$ & $151.35 \pm 5.73^{\mathrm{A}}$ & 46.09 \\
\hline Romarinic acid & $10.45 \pm 4.45^{\mathrm{B}}$ & $21.80 \pm 1.13^{\mathrm{A}}$ & 108.61 \\
\hline Tannic acid & $406.80 \pm 162.92^{\mathrm{A}}$ & $692.25 \pm 314.45^{\mathrm{A}}$ & 70.17 \\
\hline Quercetin & $10.05 \pm 1.34^{\mathrm{A}}$ & $27.65 \pm 29.20^{\mathrm{A}}$ & 175.12 \\
\hline Cinnamic acid & $60.90 \pm 1.41^{\mathrm{A}}$ & $25.05 \pm 1.34^{\mathrm{B}}$ & -58.87 \\
\hline Apigenin & $32.90 \pm 32.10^{\mathrm{A}}$ & $31.30 \pm 44.26^{\mathrm{A}}$ & -4.86 \\
\hline Kaempferol & $5.40 \pm 1.64^{\mathrm{A}}$ & $0.00 \pm 0.00^{\mathrm{B}}$ & -100.00 \\
\hline
\end{tabular}

\footnotetext{
A-B Means within a row with different letters are significantly different $(\mathrm{p}<0.05)$.

${ }^{\mathrm{C}}$ Mean $\%$ increase is calculated by phenolic contents of (blanching-control)/control x100.
} 
The results also demonstrated the amounts of the phenolics, pyrogallol, gallic acid, and cinnamic acid were higher by $22.81,39.17$, and $58.87 \%$ respectively in the CT extract, while $p$-coumaric acid, protocatechuic acid, caffeic acid, and rutin were increased in BT by 29.55, 7.56, 208.59, and $41.17 \%$ respectively (Table 2). These results are in agreement with the findings of Cai $e t a l$. [63] who reported that phenolic compounds in the aqueous extract of $C$. cassia bark contained cinnamic acid, protocatechuic acid, courmarin, and tannins as the major phenolics. Prasad et al. [22] reported that five species of Cinnamomum leaves including C. burmanni, C. cassia, $C$. pauciflorum, C. tamala, and C. zeylanica extracted by $50 \%$ ethanol contained three main flavonoids, quercetin, kaempferol, and quercitrin. Additionally, Li et al. [64] and Yang et al. [65] reported that rutin was the main flavonoid compound found in C. zeylanicum and C. cassia.

\section{Total phenolic and flavonoid contents and antioxidant activities}

Several assays are available that can be used to measure the antioxidant capacity of natural products [66]. The methods of measuring total antioxidant capacity in vitro can be classified into three groups: (1) based on hydrogen atom transfer (HAT), (2) based on single electron transfer (SET), and (3) combination of the HAT and SET mechanisms [67]. Variations in antioxidant capacities may be related to the antioxidant's structure and solubility, the partition coefficient and solvent polarity. In general, the antioxidant capacities of plant extracts depend not only on extract composition but also on the conditions of the test used [68, 69].

Any product containing TPC $\geq 5000 \mathrm{mg} / 100 \mathrm{~g}, \geq 1000<5000 \mathrm{mg} / 100 \mathrm{~g}$, and $<1000$ $\mathrm{mg} / 100 \mathrm{~g}$ can be classified as having a high, moderate or low TPC content respectively [6]. Therefore, the herbal tea in this experiment was classified as being in the moderate group, CT and BT containing TPC of around $2800 \mathrm{mg} \mathrm{GAE} / 100 \mathrm{~g}$ and $3200 \mathrm{mg} \mathrm{GAE} / 100 \mathrm{~g}$ respectively (Table $3 \mathrm{a}$ and $\mathrm{b}$ ). BT had higher values of all reference standards when compared to CT. This may be related to the phenolic and flavonoid contents shown in Table 2 as explained above. The TPC values of CT and BT were in agreement with those reported by Cai et al. [63] and Ademe et al. [70] who reported that the TPC values from a $C$. cassia bark water extract was $18.70 \mathrm{mg}$ $\mathrm{GAE} / \mathrm{g}$ and that from a $C$. zeylanicum (cinnamon) infusion was $29.32 \mathrm{mg} \mathrm{GAE} / \mathrm{g}$. Moreover, the TPC values of the extracts in the present study were higher than that of $C$. porrectum wood water extracts (26.41 mg GAE/g) [16]. As shown in Table 3b, we discovered that the ability of standard antioxidants in the samples to react with Folin reagent was in the following order: pyrogallol> caffeic acid $>$ gallic acid $>$ catechin $>p$-coumaric acid> rutin. This result supported the findings of Blainski et al. [71], who reported that the ability to react with Folin reagent of pyrogallol was the highest based on specific absorptivity and may probably represent the best reference standard for the determination of TPC due to the largest number of hydroxyl groups proportional to its molar mass. Additionally, pyrogallol has only one ring and no substituted groups, forming a three-dimensional structure with a hydroxyl that is less influenced by electronic interactions such as steric or resonance effects [72].

The TFC was analyzed based on aluminium complex formation. BT showed a higher content of TFC than CT (Table 3) using catechin and rutin as the standard references, which is strongly related to the flavonoids content of analyzed by the HPLC technique (Table 2). 
However, the metal chelating activity of the two samples was not significantly different (Table 3). We should acknolwedge that using only TFC may not be a strong indicator of metal chelating activity which is related to the free form rather than the bound form $[73,74]$.

The results in Table 4 show that there was no significant difference in the DPPH assay of CT and BT. However, BT showed higher ABTS and FRAP activity than CT. In general, the herbal tea extract in this experiment responded to the antioxidant activity assays as follows: ABTS > FRAP> DPPH. While the DPPH and ABTS assays were determined by the same mechanisms (HAT and SET), the DPPH radical is specific for methanol or ethanol solvents, while the ABTS radical can be used for a wide range of solvents including methanol or ethanol or phosphate-buffered and aqueous solvents. Additionally, the ABTS assay is more flexible and can be used at different $\mathrm{pH}$ levels compared to $\mathrm{DPPH}$, which is sensitive to an acidic $\mathrm{pH}$ [68, 69]. The steric accessibility of the $\mathrm{DPPH}^{\bullet}$ radical is a major determinant of the reaction, since small molecules that have better access to the radical site have a relatively higher antioxidant capacity. On the other hand, many large antioxidant compounds that react quickly with peroxyl radicals may react slowly or may even be inert in this assay [75]. The data from Table 4 shows that the DPPH activity with different reference standards were in the following order: pyrogallol $>$ gallic acid $>$ trolox $>$ caffeic acid $>$ catechin $>$ rutin $>>p$-coumaric acid, while the ABTS activity were in the following order: pyrogallol> gallic acid $>p$-coumaric acid $>$ catechin> caffeic acid $>>$ trolox $>$ rutin. The FRAP activity was analyzed based on the ability of antioxidants to reduce the ferric content to an intensely blue colored ferrous complex in an acidic medium $[35,76]$. The data from Table 4 shows that the FRAP activity with reference standards were in the following order: pyrogallol> gallic acid > caffeic acid> catechin $>$ rutin $>$ trolox $>>$ coumaric acid. The $p$-coumaric acid shows a poor ability to react with the DPPH radical and poor electron donating ability in the FRAP assay but has a higher ability to react with the ABTS radical $[77,78,79,80]$. However, although caffeic acid demosntrated a higher ability to react with DPPH, in the ABTS assay this compound actually demonstrated a lower ability to react than $p$-coumaric acid due to the incorporation of a hydroxyl group into $p$-coumaric acid adjacent to that in the para position, which in caffeic acid gives a TEAC of $1.56 \mathrm{mM}$ which is lower than $p$ coumaric acid $(1.99 \mathrm{mM})[63,77]$. Catechin demonstrated a higher ability to react with the DPPH and ABTS radicals than rutin. These results are in agreement with those of Cai et al [63], who reported that the radical scavenging activities of flavonoids were highly controlled by the number and configuration of phenolic hydroxyl groups. Those researchers also stated that radical scavenging activity of the different classes of the flavonoids decreased in the following order: catechin> rutin, with TEAC values of 4.21 and $1.83 \mathrm{mM}$ respectively [63].

Some researchers have used DPPH activity to determine antioxidant activity and have suggested that an $\mathrm{IC}_{50}<50 \mu \mathrm{g} / \mathrm{ml}, 50-100 \mu \mathrm{g} / \mathrm{ml}, 101-150 \mu \mathrm{g} / \mathrm{ml}$, and $>150 \mu \mathrm{g} / \mathrm{ml}$, the antioxidant activity could be classified as very strong, strong, medium, and weak respectively [81]. It can be seen that both samples in this experiment could thereby be classified as having strong antioxidant activity as the $\mathrm{IC}_{50}$ of their $\mathrm{DPPH}$ activity was about $58 \mu \mathrm{g} / \mathrm{ml}$. However, when comparing the antioxidant activity based on DPPH with that based on TPC, the level was discovered to not be the same. 
Table 3. Total phenolic, total flavonoid content, metal chelating activity, CT and BT extracts

\begin{tabular}{|c|c|c|c|c|c|c|}
\hline \multirow{2}{*}{$\begin{array}{l}\text { Ref } \\
\text { std }^{*}\end{array}$} & \multicolumn{2}{|c|}{ TPC $(\mathrm{mg} / \mathrm{g})$} & \multicolumn{2}{|c|}{ TFC (mg/g) } & \multicolumn{2}{|c|}{ Metal chelating activity $(\mathrm{mg} / \mathrm{g})$} \\
\hline & CT & BT & CT & BT & CT & BT \\
\hline PYE & $20.49 \pm 0.93^{\mathrm{B}, \mathrm{a}}$ & $22.59 \pm 0.73^{\mathrm{A}, \mathrm{a}}$ & - & - & - & - \\
\hline GAE & $25.63 \pm 0.73^{\mathrm{B}, \mathrm{bc}}$ & $28.40 \pm 0.57^{\mathrm{A}, \mathrm{bc}}$ & - & - & - & - \\
\hline $\mathbf{C E}$ & $27.93 \pm 0.94^{\mathrm{B}, \mathrm{c}}$ & $31.18 \pm 1.10^{\mathrm{A}, \mathrm{c}}$ & $4.46 \pm 0.22^{\mathrm{B}, \mathrm{a}}$ & $5.14 \pm 0.26^{\mathrm{A}, \mathrm{a}}$ & - & - \\
\hline CFE & $24.26 \pm 0.90^{\mathrm{B}, \mathrm{b}}$ & $26.80 \pm 0.84^{\mathrm{A}, \mathrm{b}}$ & - & - & - & - \\
\hline$p$-CAE & $35.15 \pm 1.10^{\mathrm{B}, \mathrm{d}}$ & $39.32 \pm 0.86^{\mathrm{A}, \mathrm{d}}$ & - & - & - & - \\
\hline RE & $57.40 \pm 1.65^{\mathrm{B}, \mathrm{e}}$ & $63.65 \pm 1.30^{\mathrm{A}, \mathrm{e}}$ & $28.34 \pm 1.64^{\mathrm{B}, \mathrm{b}}$ & $33.34 \pm 1.90^{\mathrm{A}, \mathrm{b}}$ & - & - \\
\hline TE & $92.36 \pm 3.30^{\mathrm{B}, \mathrm{f}}$ & $104.8 \pm 2.59^{\mathrm{A}, \mathrm{f}}$ & - & - & - & - \\
\hline EDTA & - & - & - & - & $4.52 \pm 0.02^{\mathrm{A}}$ & $4.58 \pm 0.05^{\mathrm{A}}$ \\
\hline
\end{tabular}

Data are means $\pm S D(n=3)$.

* Reference standards: PYE: pyrogallol, GAE: gallic acid, CE: catechin, CFE: caffeic acid, $p$ CAE: $p$-coumaric acid: RE: rutin and TE: trolox equivalent /g DW.

A-B Means are significantly different when compared CT and BT $(\mathrm{p}<0.05)$.

a-g Means are significantly different when compared with in column as different reference standards.

Table 4. The DPPH, ABTS and FRAP activities of CT and BT extracts

\begin{tabular}{ccccccc}
\hline \multirow{2}{*}{ Ref std $^{*}$ DPPH $(\mathbf{m g} / \mathbf{g})$} & \multicolumn{2}{c}{$\mathbf{A B T S}(\mathbf{m g} / \mathbf{g})$} & \multicolumn{2}{c}{ FRAP $(\mathbf{m g} / \mathbf{g})$} \\
\cline { 2 - 7 } & $\mathbf{C T}$ & $\mathbf{B T}$ & $\mathbf{C T}$ & $\mathbf{B T}$ & $\mathbf{C T}$ & $\mathbf{B}$ \\
\hline PYE & $5.22 \pm 0.08^{\mathrm{A}, \mathrm{a}}$ & $4.18 \pm 0.13^{\mathrm{A}, \mathrm{a}}$ & $6.93 \pm 0.25^{\mathrm{B}, \mathrm{a}}$ & $9.48 \pm 0.19^{\mathrm{A}, \mathrm{a}}$ & $6.45 \pm 0.11^{\mathrm{B}, \mathrm{a}}$ & $7.15 \pm 0.18^{\mathrm{A}, \mathrm{a}}$ \\
GAE & $8.18 \pm 0.16^{\mathrm{A}, \mathrm{b}}$ & $7.92 \pm 0.19^{\mathrm{A}, \mathrm{b}}$ & $18.46 \pm 0.25^{\mathrm{B}, \mathrm{b}}$ & $21.93 \pm 0.26^{\mathrm{A}, \mathrm{b}}$ & $7.82 \pm 0.12^{\mathrm{B}, \mathrm{b}}$ & $8.58 \pm 0.19^{\mathrm{A}, \mathrm{b}}$ \\
CE & $15.20 \pm 0.25^{\mathrm{A}, \mathrm{d}}$ & $15.00 \pm 0.18^{\mathrm{A}, \mathrm{d}}$ & $29.22 \pm 0.64^{\mathrm{B}, \mathrm{d}}$ & $34.72 \pm 1.14^{\mathrm{A}, \mathrm{d}}$ & $23.90 \pm 0.38^{\mathrm{B}, \mathrm{d}}$ & $26.40 \pm 0.63^{\mathrm{A}, \mathrm{d}}$ \\
CFE & $12.74 \pm 0.41^{\mathrm{A}, \mathrm{c}}$ & $12.58 \pm 0.48^{\mathrm{A}, \mathrm{c}}$ & $37.70 \pm 0.28^{\mathrm{B}, \mathrm{e}}$ & $40.66 \pm 1.40^{\mathrm{A}, \mathrm{e}}$ & $14.22 \pm 0.22^{\mathrm{B}, \mathrm{c}}$ & $20.85 \pm 0.22^{\mathrm{A}, \mathrm{c}}$ \\
$p$-CAE & $90.35 \pm 1.06^{\mathrm{A}, \mathrm{f}}$ & $95.35 \pm 1.77^{\mathrm{A}, \mathrm{f}}$ & $23.81 \pm 0.39^{\mathrm{B}, \mathrm{c}}$ & $27.98 \pm 0.56^{\mathrm{A}, \mathrm{c}}$ & $104.49 \pm 1.57^{\mathrm{B}, \mathrm{f}}$ & $152.64 \pm 1.57^{\mathrm{A}, \mathrm{f}}$ \\
RE & $56.76 \pm 0.47^{\mathrm{A}, \mathrm{e}}$ & $57.64 \pm 0.79^{\mathrm{A}, \mathrm{e}}$ & $116.41 \pm 2.94^{\mathrm{B}, \mathrm{g}}$ & $126.22 \pm 1.31^{\mathrm{A}, \mathrm{g}}$ & $36.98 \pm 0.57^{\mathrm{B}, \mathrm{e}}$ & $54.31 \pm 0.57^{\mathrm{A}, \mathrm{e}}$ \\
TE & $14.30 \pm 0.07^{\mathrm{A}, \mathrm{d}}$ & $14.43 \pm 0.12^{\mathrm{A}, \mathrm{d}}$ & $93.71 \pm 2.88^{\mathrm{B}, \mathrm{f}}$ & $102.26 \pm 1.14^{\mathrm{A}, \mathrm{f}}$ & $37.90 \pm 0.65^{\mathrm{B}, \mathrm{e}}$ & $57.90 \pm 0.65^{\mathrm{A}, \mathrm{e}}$ \\
\hline
\end{tabular}

Data are means $\pm \mathrm{SD}(\mathrm{n}=3)$.

* Reference standards: PYE: pyrogallol, GAE; gallic acid, CE; catechin, CFE; caffeic acid, $p$ $\mathrm{CAE}$; $p$-coumaric acid; RE; rutin and TE; trolox equivalent /g DW.

A-B Means are significantly different when compared CT and BT $(\mathrm{p}<0.05)$.

a-g Means are significantly different when compared within column for different reference standards.

\section{Effect of $C$. porrectum herbal tea extract on cell viability}

In order to avoid possible cytotoxic effects from the extracts on NO inhibition, the effect on cell viability of the extracts was initially determined using the MTT method. Samples at concentrations of 0.01 to $2000 \mu \mathrm{g} / \mathrm{ml}$ were added to RAW 264.7 cells for 24 hours before the cell viability was measured by MTT assay. The results demonstrated that CT and BT extracts at concentrations were lower than $50 \mu \mathrm{g} / \mathrm{ml}$ and provided 80 and $83 \%$ cell viability (Figure 3), and thereby can be classified in the non-toxic category [82]. Therefore, this concentration was selected for further study. 


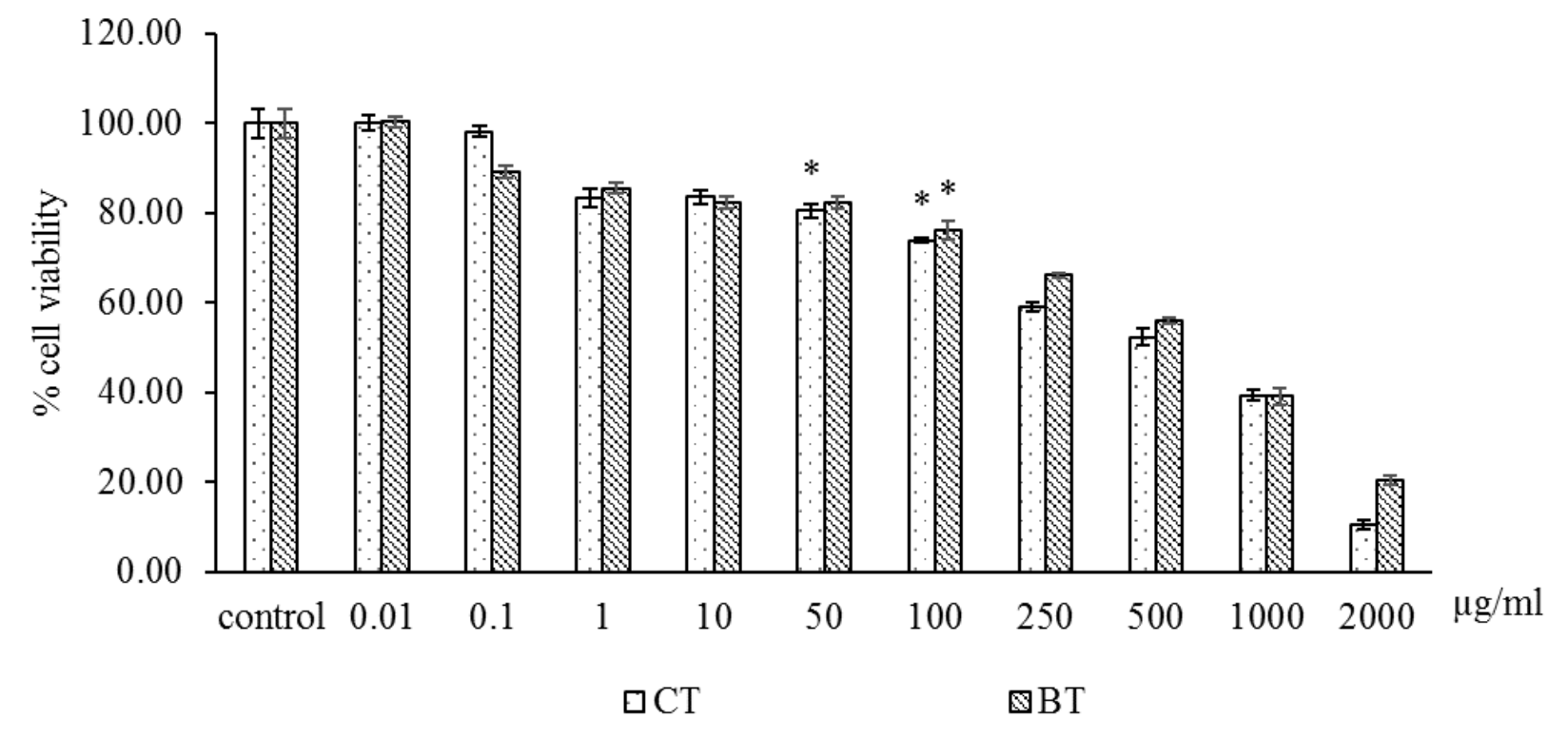

Figure 3. Effect of C. porrectum herbal tea extracts (CT and BT) on cytotoxicity of RAW 264.7 cells measured by MTT assay. Cells were incubated for $24 \mathrm{~h}$ with the absence or presence of samples $(0.01,0.1,1,10,50,100,250,500,1000$ and $2000 \mu \mathrm{g} / \mathrm{ml})$. Results are mean $\pm \mathrm{SD}$ $(n=3)$.

* mean percentage of cell viability less than $80 \%$.

\section{Nitric oxide inhibition activity}

Macrophages are known to play an important role in inflammation through the production of several pro-inflammatory molecules, including nitric oxide (NO). The inhibitory activity of the extracts, phenolics, and flavonoids on NO inhibition was evaluated in the RAW 264.7 cell line treated with LPS to induce over-expression of inducible nitric oxide synthase (iNOS) in order to create inflammation [83]. Generally, foods and phytochemicals exert NO-suppressing activity via three different pathways: (1) the blocking of iNOS expression, (2) the inactivation of the iNOS catalytic function, and (3) the scavenging of NO [84, 85]. The NO inhibition ability and the percentage cell viability of extracts are shown in Figure 4 (A and B). However, the $\mathrm{IC}_{50}$ for NO inhibition in the CT sample could not be investigated because of its high toxicity. On the other hand, since BT showed NO inhibition of $52.30 \%$ ( $\mathrm{IC}_{50} 42.29 \mu \mathrm{g} / \mathrm{ml}$ ), this may have been due to the higher total extractability of phenolics and flavonoids and higher antioxidant activities (Table 3 and 4) but lower quantities of toxic agents including safrole and methyleugenol (Figure 2).

The study of Pukdeekumjorn et al. [16] reported that $C$. porrectum wood water extracts showed $\mathrm{IC}_{50}$ values of more than $100 \mu \mathrm{g} / \mathrm{ml}$, which was lower than both the CT and BT extracts. This may be due to the TPC content of the leaves being higher than that of the wood sample. However, the NO inhibition of both extracts was lower than that of the C. porrectum wood when extracted with 50 and $95 \%$ ethanol ( $\mathrm{IC}_{50}$ values of $19.28 \pm 2.43$ and $13.78 \pm 3.76 \mu \mathrm{g} / \mathrm{ml}$ respectively) and the $\mathrm{IC}_{50}$ value of $95 \%$ ethanolic extract from C. cassia bark was $36 \mu \mathrm{g} / \mathrm{ml}$ [86]. Moreover, the results in the present experiment support the findings of Chen and Zhang. [87], 
specifically in how using $100 \mu \mathrm{g} / \mathrm{ml}$ of $C$. cassia Presl twig and bark extracted by $70 \%$ ethanol to treat RAW 264.7 cells resulted in NO inhibitions of 38.43 and $68.31 \%$ respectively.

The NO inhibition abilities of standard phenolics and flavonoids are shown in Figure 5 (A and B). Among the six phenolics and flavonoids tested, the NO inhibition activity was in close agreement with the antioxidant properties and was in the following order: gallic acid $\geq$ pyrogallol $>$ caffeic acid > rutin > catechin > p-coumaric acid with $\mathrm{IC}_{50}$ values of 21.36, 21.50, 28.76, 52.54, 70.60, and $80.94 \mu \mathrm{g} / \mathrm{ml}$ respectively. However, gallic acid and pyrogallol provided higher NO inhibition, higher concentrations of more than $30 \mu \mathrm{g} / \mathrm{ml}$ also induced cell death greater than 20\% (Figure 5 A and B). This result supports the study of Wang and Mazza [88], who reported that gallic acid resulted in a decrease of cell viability at a concentration of $500 \mu \mathrm{M}(85.06$ $\mu \mathrm{g} / \mathrm{ml}$ ). According to the results of Ho et al [89], $100 \mu \mathrm{M}$ of caffeic acid, $p$-coumaric acid, and rutin provided NO inhibition of $71.3 \%, 50.0 \%$, and $40.9 \%$ respectively, while catechin did not show any inhibitory activity. The NO inhibition of both the extracts seems to have been lower than the pure phenolic standards such as pyrogallol and gallic acid, which may be due to the effects of conjugation or being in the bound form [88, 89, 90].
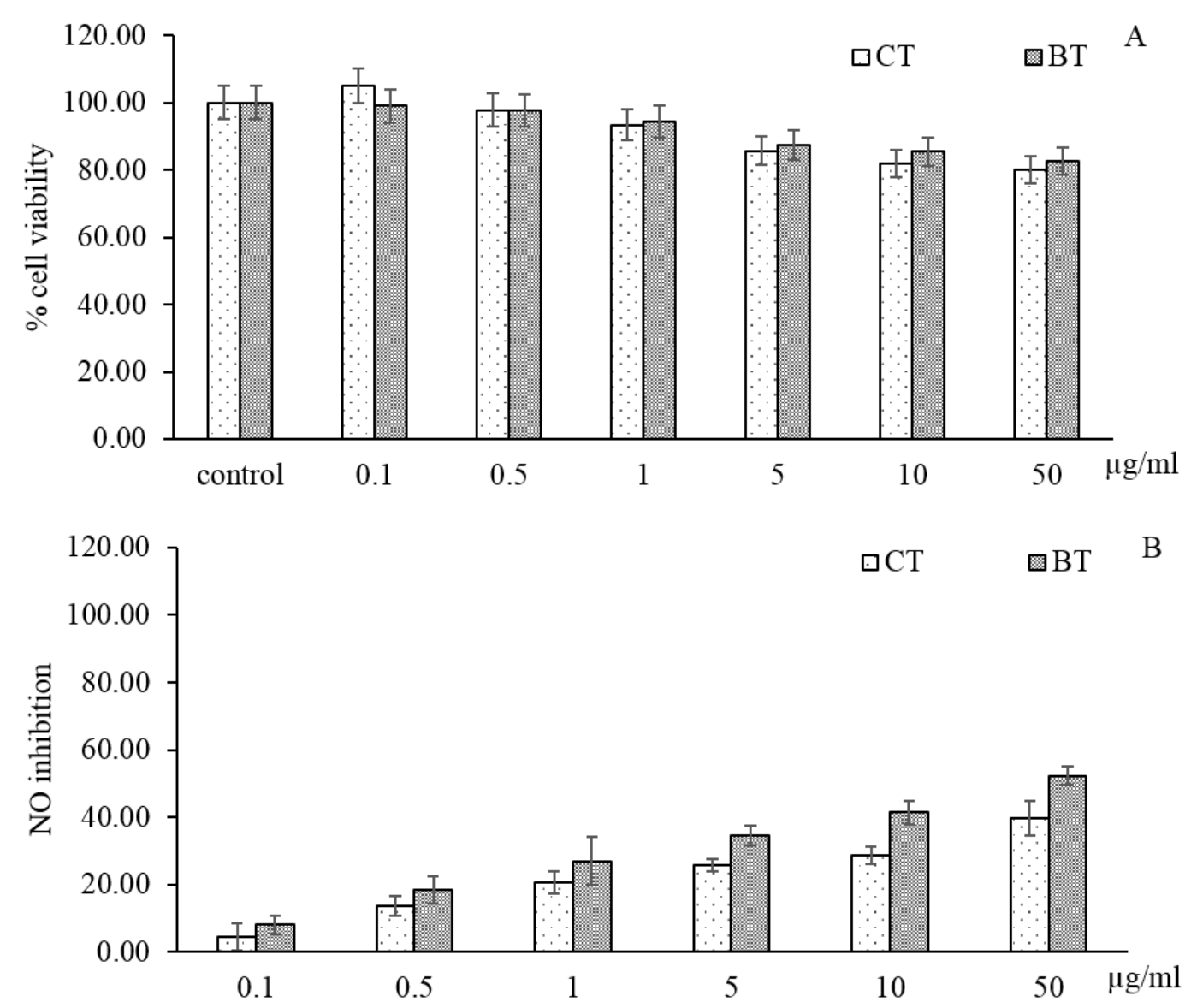

Figure 4. Effect of $C$. porrectum herbal tea extracts (CT and BT) on cell viability (A) and NO inhibition (B) of LPS-stimulated RAW 264.7 cells. Cells were incubated for $24 \mathrm{~h}$ with $0.5 \mu \mathrm{g} / \mathrm{ml}$ of LPS in the absence (-) or presence of samples $(0.1,0.5,1,5,10$, and $50 \mu \mathrm{g} / \mathrm{ml})$. 


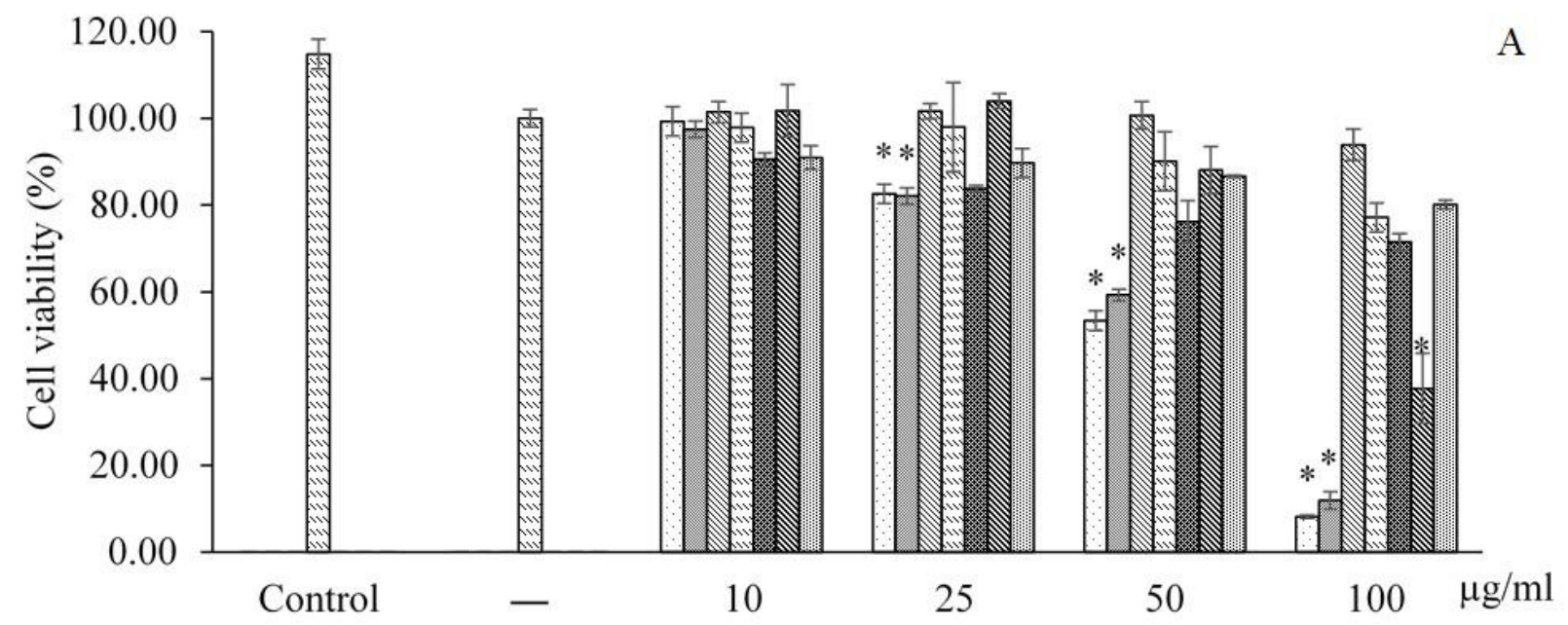

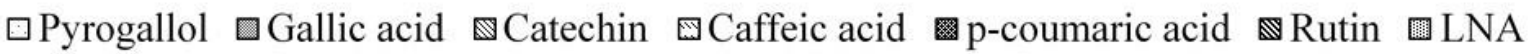

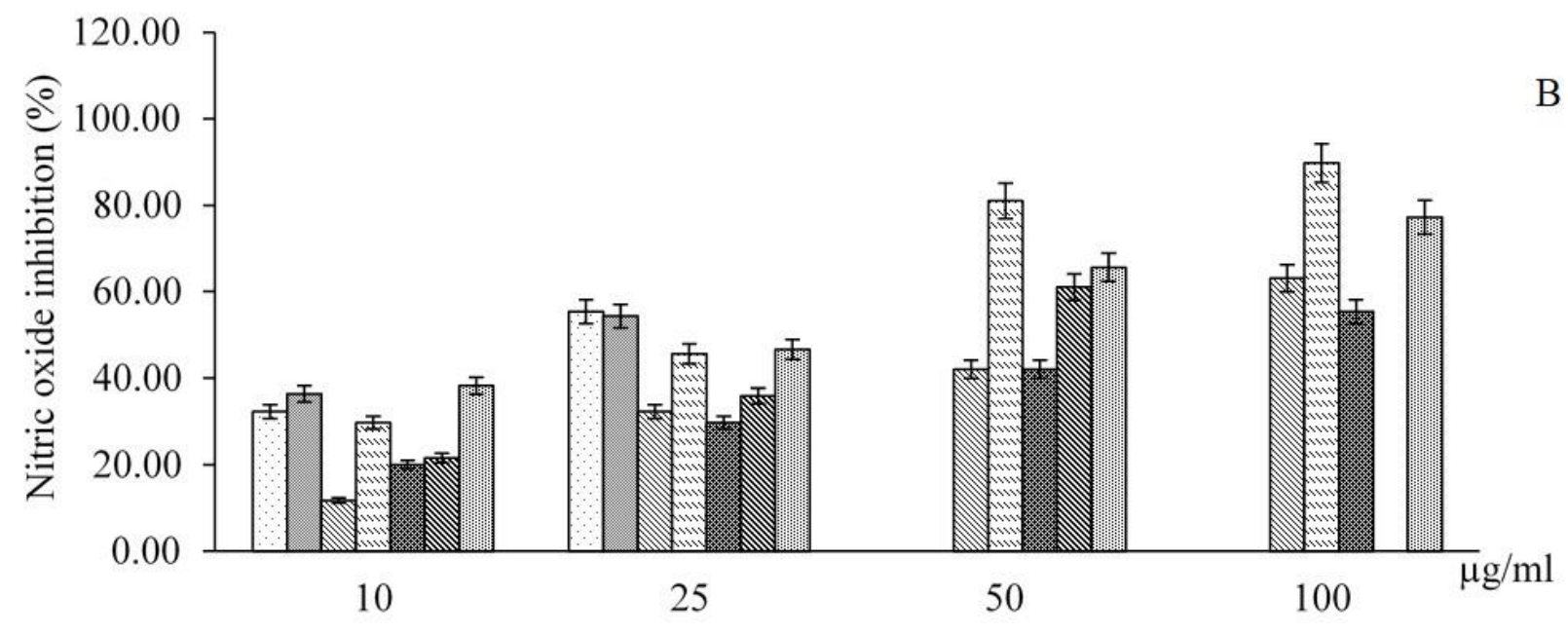

$\square$ Pyrogallol $\square$ Gallic acid $\mathbb{\otimes}$ Catechin $\otimes$ Caffeic acid $\mathbf{m}$ p-coumaric acid $\mathbb{\Delta}$ Rutin $\square$ LNA

Figure 5. Effect of phenolics, flavonoids, and LNA on cell viability (A) and NO inhibition (B) of LPS-stimulated RAW 264.7 cells. Cells were incubated for $24 \mathrm{~h}$ with $0.5 \mu \mathrm{g} / \mathrm{ml}$ of LPS in the absence (-) or presence of phenolics, flavonoids and LNA (10, 25, 50 and $100 \mu \mathrm{g} / \mathrm{ml})$.

* mean percentage of cell viability less than $80 \%$.

\section{CONCLUSION}

The results confirmed that safrole is the major chemical constituent in CWO, followed by elemicin and methyleugenol. The C. porrectum leaves methanolic extracts analyzed by the GCMS technique consisting of methyleugenol, safrole, and caryophyllene. The blanching process significantly decreased both safrole and methyleugenol content by $89 \%$ and $87 \%$ and by $68 \%$ and $62 \%$ when compared to the hot air dried and freeze-dried samples respectively. Additionally, the blanching process reduced cytotoxicity in macrophage cells while increasing TPC, TFC, ABTS, and FRAP activities. The phenolic profile was more rebust in the blanched leaves sample when compared to the un-treated sample. 
List of Abbreviations: DPPH, 1, 1-diphenyl-2-picryl-hydrazyl; ABTS, 2, 2'-azino-bis (3ethylbenzthiazoline-6-sulfonic acid); FRAP, Ferric reducing antioxidant power.

Competing Interests: None to declare.

Authors' Contributions: Phornthip Saetan, BSc- PhD is a Food Technologist and performed all of the laboratory work for the study in addition to providing statistical analysis and assisting in the writing of the manuscript. Worapong Usawakesmanee, PhD is a Food Technologist. He was the principal investigator for this study, providing oversight and contributing fundamental conceptualization for the research, as well as writing the grant proposal and the manuscript. Sunisa Siripongvutikorn, PhD is an Assistant Professor of Food Technology. She initiated and accelerated the development and (subsequent) production of the intervention drink. She also contributed in the study design and assisted in writing the manuscript. Chutha Takahashi Yupanqui, PhD is an interdisciplinary Graduate School of Nutraceutical and Functional Food (IGS-NFF) lecturer. She is a research coordinator who provided remarks and suggestions about the cell culture technique such as anti-inflammatory and anti-cancer properties as well as verifying the correction of the manuscript.

Acknowledgements and Funding: The authors would like to thank the Graduate School of Prince of Songkla University, Thailand, for their financial support. Financial support was provided by a Grant-in-aid for dissertation from the Graduate School, Prince of Songkla University, Thailand.

\section{REFERENCES}

1. Durackova Z: Some current insights into oxidative stress. Physiol Res 2010, 59: 459-469.

2. Ambriz-Pérez DL, Leyva-López N, Gutierrez-Grijalva EP, Heredia JB: Phenolic compounds: Natural alternative in inflammation treatment-A Review. Food Sci Technol 2016, 2: 1-14.

3. Khandrika, Kumar B, Koul S, Maroni P, Koul HK: Oxidative stress in prostate cancer. Cancer Lett 2009, 282: 125-136.

4. Bergamini CM, Gambetti S, Dondi A, Cervellati C: Oxygen, reactive oxygen species and tissue damage. Curr Pharm Des 2004, 10: 1611-1626.

5. Afonso V, Champy R, Mitrovic D, Collin P, Lomri A: Reactive oxygen species and superoxide dismudase: role in joint disease. Joint Bone Spine 2007, 74: 324-329.

6. Chan EWC, Eng SY, Tan YP, Wong ZC, Lye PY, Tan LN: Antioxidant and sensory properties of Thai herbal teas with Emphasis on Thunbergia laurifolia Lindl. Chiang Mai J Sci 2012, 39: 599-609.

7. Chan CL, Gan RY, Corke H: The phenolic composition and antioxidant capacity of soluble and bound extracts in selected dietary spices and medicinal herbs. Int J Food Sci Technol 2016, 51: 565-573.

8. Gunawardena D, Bennett L, Shanmugam K, King K, Williams R, Zabaras D, Head R, Ooi L, Gyengesi E, Munch G: Anti-inflammatory effects of five commercially available mushroom species determined in lipopolysaccharide and interferon- $\gamma$ activated murine macrophages. Food Chem 2014, 148: 92-96.

9. Chang HY, Sheu MJ, Yang CH: Analgesis effects and the mechanisms of antiinflammation of hispolon in mice. J Evid Based Complementary Altern Med 2009, 2011: $1-8$. 
10. Moncada S, Palmer RMJ, Higgs EA: Nitric oxide: physiology, pathophysiology, and pharmacology. Pharmacol Rev 1991, 43: 109-141.

11. Liao JC, Deng JS, Chiu CS, Hos WC, Huang SS, Shie PH, Huang GJ: Anti-inflammatory activities of Cinnamomum cassia constituents in vitro and in vivo. $\mathrm{J}$ Evid Based Complementary Altern Med 2012, 2012: 1-12.

12. Joo T, Sowndhararajan K, Hong S, Lee J, Park SY, Kim S, Jhoo JW: Inhibition of nitric oxide production in LPS-stimulated RAW 264.7 cells by stem bark of Ulmus pumila L. Saudi J Biol Sci 2014, 21: 427-435.

13. Tiwari M, Dwivedi UN, Kakkar P: Suppression of Oxidative Stress and ProInflammatory Mediators by Cymbopogon Citratus D. Stapf Extract in Lipopolysaccharide Stimulated Murine Alveolar Macrophages. Food Chem Toxicol 2010, 48: 2913-2919.

14. European Pharmacopoeia General Monograph "Herbal Teas" 01/2008:1435.

15. European Pharmacopoeia General Chapter "Microbiological quality of medicinal products containing herbal drugs and/or herbal drug preparations" 04/2010:50108.

16. Pukdeekumjorn $\mathrm{P}$, Reuangnoo $\mathrm{S}$, Panthong $\mathrm{S}$, Itharat $\mathrm{A}$ : In vitro antioxidant, antiinflammatory and anyimicrobial activities of Cinnamomum porrectum wood (Thep-TaRo). Sci-Health 2012, 19: 1-6.

17. Subki SYM, Jamal JA, Husain K, Manshoor N: Characterisation of leaf essential oils of three Cinnamomum species from Malaysia by gas chromatography and multivariate data analysis. Phcog J 2013, 8: 22-29.

18. bin Jantan I, Goh SI: Essential oils of Cinnamomum species from peninsular Malaysia. J Essent Oil Res 1992, 4: 161-171.

19. Singh G, Maurya S, deLampasona M. P, Catalan CAN: A comparison of chemical, antioxidant and antimicrobial studies of cinnamon leaf and bark volatile oils, oleoresins and their constituents. Food Chem. Toxicol 2007, 45: 1650-1661.

20. Prasad KN, Yang B, Dong X, Jiang G, Zhang H, Xie H, Jiang Y: Flavonoid contents and antioxidant activities from Cinnamomum species. Innov Food Sci Emerg Technol 2009, 10: 627-632.

21. Wang R, Wang R, Yang B: Extraction of essential oils from cinnamon leaves and identification of their volitile compound composition. Innovat Food Sci Emerg Tech 2008, 10: 289-292.

22. Reynertson KA, Balick MJ, Lee R, Raynor W, Pelep Y, Kennelly EJ: A traditional method of Cinnamomum carolinense preparation eliminates safrole from a therapeutic Pohnpean tea. J Ethnopharmacol 2005, 102: 269-274.

23. IARC (International Agency for Research on Cancer): IARC Monographs on the Evaluation of the Carcinogenic Risks to Humans. In Overall Evaluations of Carcinogenicity. Edited by An Updating of IARC Monographs. Lyon. France; 1987: 142.

24. European Food Safety Authority: Compendium of Botanicals That Have Been Reported to Contain Toxic, Addictive, Psychotropic or Other Substances of Concern on Request of EFSA. Volume. 9. EFSA Journal; 2009: 7: 1-100.

25. Budavari S: The merck index. Merck \& Co., Rahway, NJ, p. 8286.

26. Cheng SS, Chang HT, Lin CY, Chen PS, Huang CG, Chen WJ, Chang ST: Insecticidal activities of leaf and twig essential oils from Clausena excavata against Aedes aegypti and Aedes albopictus larvae. Pest Manag Sci 2009, 65: 339-343.

27. Chen C, Spriano D, Lehmann T, Meier B: Reduction of safrole and methyleugenol in Asari radix et rhizoma by decoction. Forsch Komplementmed 2009, 16: 162-166. 
28. Tan KH, Nishida R: Methyl eugenol: Its occurrence, distribution, and role in nature, especially in relation to insect behavior and pollination. Int J Insect Sci 2011, 12: 1-74.

29. Tung YT, Chua MT, Wang SY, Chang ST: Anti-inflammation activities of essential oil and its constituents from indigenous cinnamon (Cinnamomum osmophloeum) twigs. Bioresour Technol 2008, 99: 3908-3913.

30. AOAC: Association of Official Analytical Chemists: Official Method of Analysis: Official Method of Analysis: Washington D.C. Press; 2000.

31. Nelson N: A Photometric adaptation of the Somogyi method for the determination of glucose. from the May Institute for Medical Research of the Jewish Hospital, and the Department of Biological Chemistry, College of Medicine, University of Cincinnati, Cincinnati 1944, 1-7.

32. Lowry OH, Rosebrough NJ, Farr AL, Randall RJ: Protein measurement with the Folin phenol reagent. J Biol Chem 1951, 193: 265-75.

33. Udayaprakash NK, Bhuvaneswari S, Sripaiya N, Prameela L, Bhagya R, Radhika B, Balamurugan A, Arokiyaraj S: Antioxidant activity of common plants of northern Tamil Nadu, India, Int J Pharm Sci 2014, 4: 128-132.

34. Arnao MB, Cano A, Alcolea JF, Acosta M: Estimation of free radical-quenching activity of leaf pigment extracts. Phytochem Anal 2001, 2: 138-143.

35. Benzie IFF, Strain JJ: The ferric reducing ability of plasma (FRAP) as a measure of antioxidant power the FRAP assay. Anal Biochem1996, 239: 70-76.

36. Boyer LC, McCleary CJ: Superoxide ion as a primary reductant in ascorbate-mediated ferritin iron release. Free Rad Bio Med 1987, 3: 389-395.

37. Tewtrakul S, Subhadhirasakul S, Karali C, Ponglimanont C, Cheenpracha S: Antiinflammatory effects of compounds from Kaempferia parviflora and Boesenbergia pandurata. Food Chem 2009, 115: 534- 538.

38. Sae-Wong C, Matsuda H, Tewtrakul S, Tansakul P, Nakamura S, Nomura Y, Yoshikawa M: Suppressive effects of methoxyflavonoids isolated from Kaempferia parviflora on inducible nitric oxide synthase (iNOS) expression in RAW 264.7 cells. J Ethnopharmacol 2011, 136: 488-495.

39. Matsuda H, Morikawa T, Ando S, Toguchida I, Yoshikawa M: Structural requirements of flavonoids for nitric oxide production inhibitory activity and mechanism of action. Bioor Med Chem 2003, 11:1995-2000.

40. Pattanaseree, T, Anantachoke, N: Chemical constituents in volatile oils of Cinnamomum porrectum (Roxb.) Kosterm from Pang-nga and Songkhla provinces. In Annual Report of Research. (Semsuntud, N., ed.). Royal Forest Department, Bangkok 2012, 243- 252.

41. Tomlin CDS: Methyl Eugenol (93-15-2). In: The e-Pesticide Manual, 13th Edition Version 3.0 (2003-04). Surrey UK, British Crop Protection Council.

42. Charles DJ, Simon JE: Comparison of Extraction Methods for the Rapid Determination of Essential Oil Content and Composition of Basil. J Amer Soc Hort Sci 1990, 115: 458462.

43. Okoh OO, Afolayan AJ: The effects of hydrodistillation and solvent free microwave extraction methods on the chemical composition and toxicity of essential oils from the leaves of Mentha longifolia L. subsp. capensis. Afr J Pharm Pharacol 2011, 5: 24742478.

44. Diaz-Maroto MC, Gonzalez-Vinas MA, Cabezudo MD: Evaluation of the effect of drying methods on the volatile compounds of parsley (Petroselinum crispum L.). Eur Food Res Technol 2003, 215: 227-230. 
45. Diaz-Maroto M, Cabezudo MD: Influence of drying on the flavor quality of speamint (Mentha spicata L.). J Agric Food Chem 2003, 51:1265-1269.

46. Ozilgen M, Ozdemir M: A review on grain and nut deterioration and design of the dryers for safe storage with special reference to Turkish hazelnuts. Crit Rev Food Sci Nutr 2001, 41: $95-132$.

47. Saetan P, Uksawakesmanee W, Siripongvitikorn S: Influence of hot water blanching process on nutritional content, microstructure, antioxidant activity and phenolic profile of Cinnamomum porrectum herbal tea. Funct Food Health Dis 2016, 6: 836-854.

48. Dugo G, Lapera L, Turco VL, Palmieri RM, Saitta M: Effect of boiling and peeling on manganese content of some vegetables determined by derivative anodic stripping chronopotentiometry (dASCP). Food Chem 2005, 93, 703-711.

49. Lewu MN, Adebola PO, Afolagan AJ: Effect of cooking on the mineral contents and anti-nutritional factors in seven accessions of Colocasia esculenta (L.) Schott growing in South Afric. J Food Compos Anal 2010, 23, 389-393.

50. Song JY, An GH, Kim CJ: Color, texture, nutrient contents, and sensory values of vegetable soybeans (Glycine $\max$ (L.) Merrill) as affected by blanching. Food Chem 2003, 83: 69-74.

51. Cheftel JC, Cuq J, Lorient D: Amino acids, peptides, and proteins. In Food chemistry. $2^{\text {nd }}$ edition. Edited by Fennema OR. New York: Marcel Dekker; 1985: 245-369.

52. Sila DN, Buggenhout SV, Duvetter T, Fraeye I, Roeck AD, Loey AV, Hendrickx M: Pectins in processed fruits and vegetables: Part II-Structure-Function Relationships. Compr Rev Food Sci Food Saf 2009, 8: 86-104.

53. Deylami MZ, Rahman RA, Tan CP, Bakar J, Olusegun: Effect of blanching on enzyme activity, color changes, anthocyanin stability and extractability of mangosteen pericarp: A kinetic study. Food Eng 2016, 178: 12-19.

54. Stamatopoulos K, Katsoyannos E, Chatzilazarou A, Konteles SJ: Improvement of oleuropein extractability by optimizing steam blanching process as pre-treatment of olive leaf extraction via response surface methodology. Food Chem 2016, 133: 344-351.

55. Ando Y, Maeda Y, Mizutani K, Wakatsuki N, Hagiwara S, Nabetani H: Impact of blanching and freeze-thaw pre-treatment on drying rate of carrot roots in relation to changes in cell membrane function and cell wall structure. LWT- Food Sci Technol 2016, 71: 40-46.

56. Vergara-Salinas JR, Vergara M, Altamirano C, Gonzalez A, Perez-Correa JR: Characterization of pressurized hot water extracts of grape pomace: Chemical and biological antioxidant activity. Food Chem 2015, 171: 62-69.

57. Nicoletti I, Martini D, De Rossi A, Taddei F, D'Egidio MG, Corradini D: Identification and quantification of soluble free, soluble conjugated, and insoluble bound phenolic acids in durum wheat (Triticum turgidum L. var. durum) and derived products by RP-HPLC on a semimicro separation scale. J Agric Food Chem 2013, 61: 11800-11807.

58. Saulnier L, Crépeau MJ, Lahaye M, Thibault JF, Garcia-Conesa MT, Kroon PA, Williamson G: Isolation and structural determination of two 5,5\%-diferuloyl oligosaccharides indicate that maize heteroxylans are covalently cross-linked by oxidatively coupled ferulates. Carbohydr Res 1999, 320: 82-92.

59. Sun L, Zhang H, Zhuang Y: Preparation of free, soluble conjugate, and insoluble-bound phenolic compounds from peels of rambutan (Nephelium lappaceum) and evaluation of antioxidant activities in vitro. J Food Sci 2012, 77: 198- 204.

60. Yokotsuka K, Singleton VL: Interactive precipitation between phenolic fractions and peptides in wine-like model solutions: Turbidity, particle size, and residual content as 
influenced by $\mathrm{pH}$, temperature and peptide concentration. Am J Enol Vitic 1995, 46: 329-338.

61. Zhang Y, Wang L, Yao Y, Yan J, He ZH: Phenolic acid profiles of Chinese wheat cultivars. J Cereal Sci 2012, 56: 629-635.

62. Hawthorne SB, Miller DJ, Lagadec AJM, Hammond PJ, Clifford AA: Method of manipulating the chemical properties of water to improve the effectiveness of a desired process. Volume 6. Edited by Energy and Environmental Research Center Foundation. United States of America: United States Patent; 2002, 6: 352-644.

63. Cai YZ, Sun M, Xing J, Luo Q, Corke H: Structure-radical scavenging activity relationships of phenolic compounds from traditional Chinese medicinal plants. Life Sci 2006, 78: 2872-2888.

64. Li HB, Wong C C, Cheng KW, Chen F: Antioxidant properties in vitro and total phenolic contents in methanol extracts from medicinal plants. LWT-Food Sci Technol 2008, 41: 385-390.

65. Yang CH, Li RX, Chuang LY: Antioxidant activity of various parts of Cinnamomum cassia extracted with different extraction methods. Molecules 2012, 17: 7294-7304.

66. Galano A, Mazzone G, Alvarez-Diduk R, Marino T, Alvarez-Odaboy JR, Russo N: Food antioxidants: chemical insights at the molecular level. Annu Rev Food Sci Technol 2015, 7: 335-352.

67. Liang N, Kitts D: Antioxidant property of coffee components: assessment of methods that define mechanisms of action. Molecules 2014, 19: 19180-19208.

68. Ou B, Hampsch-Woodill M, Prior RL: Development and validation of an improved oxygen radical absorbance capacity assay using fluorescein as the fluorescent probe. $\mathrm{J}$ Agric Food Chem 2001, 49: 4619-4626.

69. Shalaby EA, Shanab SMM: Comparison of DPPH and ABTS assays for determining antioxidant potential of water and methanol extracts of Spirulina platensis. Indian J Mar Sci 2013. 42: 556-564.

70. Ademe RS, Torres LM, Infante JAG, Calderas F, Laredo RFG, Guzman NER, Martinez LAO, Bernad MJB: Spray drying-microencapsulation of cinnamon infusions (Cinnamomum zeylanicum) with maltodextrin. LWT- Food Sci Technol 2015, 64: 571577.

71. Blainski A, Lopes GC, Mello JCP: Application and analysis of the folin ciocalteu method for the determination of the total phenolic content form Limonium brasiliense L. Molecules 2013, 18: 6852-6865.

72. Kaewnarin K, Suwannarach N, Kumla J, Lumyong S: Phenolic profile of various wild edible mushroom extracts from Thailand and their antioxidant properties, anti-tyrosinase and hyperglycaemic inhibitory activities. J Funct Food 2016, 27: 352-364.

73. Chandrasekara A, Shahidi F: Content of insoluble bound phenolics in millets and their contribution to antioxidant capacity. J Agric Food Chem 2010, 58:6706-6714.

74. Symonwicz M, Kolabek M: Flavonoids and their properties to form chelate complexes. Biotechnol Food Sci 2012, 76: 35-41.

75. Apak R, Güçlü K, Demirata B, Özyürek M, Çelik SE, Bektaşoğlu B, Berker KI, Özyurt D: Comparative evaluation of various total antioxidant capacity assays applied to phenolic compounds with the CUPRAC assay. Molecules 2007, 12: 1496-1547.

76. Gülçin I: Antioxidant activity of food constituents: an overview. Arch Toxicol 2012, 86: 345-391.

77. Block G, Langseth L: Antioxidant vitamins and disease prevention. Food Technol 1994, 80-84. 
78. Brand-Williams W, Cuvelier ME, Berset C: Use of a free radical method to evaluate antioxidant activity. Lebensm Wiss Technol 1995, 28: 25-30.

79. Galato D, Ckless K, Susin MF, Giabomelli C, Riveirodo-Calle RM, Spinelli A: Antioxidant capacity of phenolic and related compounds: correlation among electrochemical, visible spectroscopy methods and structure-antioxidant activity. Redox Rep 2001, 6: 243-250.

80. Teixeira J, Gaspar A, Garrido EM, Garrido J, Borges F: Hydroxycinnamic acid antioxidants: an electrochemical overview. Bio Med Res Int 2013, 62: 289-296.

81. Fidrianny I, Rizkiya A, Ruslan K: Antioxidant activities of various fruit extracts from three solanum sp. Using DPPH and ABTS method and correlation with phenolic, flavonoid and carotenoid content. J Chem Pharm Res 2015, 7: 666-672.

82. Panichayupakaranan P, Tewrakul S, Yuenyongsawad S: Antibacterial anti-inflammatory and antiallergic activities of standardized pomegranate rind extract. Food Chem 2010, 123: 400-403.

83. Hobbs A, Higgs A, Moncada S: Inhibition of nitric oxide synthase as a potential therapeutic target. Annu Rev Pharmacol Toxicol 1999, 39: 191-220.

84. Sheu F, Yen GC: Modulation of nitric oxide production by foodstuffs. Food Sci Agric Chem 2001. 3: 42-58.

85. Tsai PJ, Tsai TH, Yu CH, Ho SC: Evaluation of NO suppressing activity of several Mediterranean culinary spices. Food Chem Toxicol 2007, 45: 440-447.

86. Yu HS, Lee SY, Jang CG: Involvement of 5-HT1A and GABAA receptors in the anxiolytic-like effects of Cinnamomum cassia in mice. Pharmacol Biochem Behav 2007, 87: 164-170.

87. Chen CL, Zhang DD: Anti-Inflammatory Effects of 81 Chinese Herb Extracts and Their Correlation with the Characteristics of Traditional Chinese Medicine. Evid Based Complement Alternat Med 2014, 2014: 1-11.

88. Wang J, Mazza G: Effects of anthocyanins and other phenolic compounds on the production of tumor necrosis factor $\mathrm{r}$ in LPS/IFN- $\boldsymbol{\gamma}$-activated RAW 264.7 macrophages. $\mathrm{J}$ Agric Food Chem 2002, 50: 4183-4189.

89. Ho GTT, Wangensteen H, Barsett H: Elderberry and elderflower extracts, phenolic compounds, and metabolites and their effect on complement, RAW 264.7 macrophages and dendritic cells. Int J Mol Sci 2017, 18: 2-17.

90. Hämäläinen M, Nieminen R, Vuorela P, Heinonen M, Moilanen E: Anti-inflammatory effects of flavonoids: Genistein, kaempferol, quercetin, and daidzein inhibit STAT-1 and $\mathrm{NF}-\kappa \mathrm{B}$ activations, whereas flavone, isorhamnetin, naringenin, and pelargonidin inhibit only NF- $\kappa \mathrm{B}$ activation along with their inhibitory effect on iNOS expression and NO production in activated macrophages. Mediat Inflamm 2007: 1-10. 